\title{
Composition of Sewage and Non-Sewage Water of Different District of Haryana, India
}

\author{
Sushil*, R. S. Garhwal and Dinesh \\ Department of Soil Science, CCS Haryana Agricultural University Hisar-125004, India \\ *Corresponding author
}

\section{A B S T R A C T}

\section{Keywords \\ Chemical oxygen demand, Biological oxygen demand, sewer water, cadmium, cobalt, lead \\ Article Info \\ Accepted: \\ 24 August 2019 \\ Available Online: \\ 10 September 2019}

Raw sewer and tube well water samples were collected from various sewer disposal sites and nearby fields in Kurukshetra, Kaithal, Narwana, Jind and Charkhi Dadri (Haryana) where these waters are directly used for irrigating the crops. The mean values of $\mathrm{pH}$ (8.49), electrical conductivity (1.91 $\left.\mathrm{dSm}^{-1}\right)$, chemical oxygen demand $\left(762.0 \mathrm{mg} \mathrm{L}^{-1}\right)$ and biological oxygen demand $\left(227.5 \mathrm{mg} \mathrm{L}^{-1}\right)$ were highest in sewage water of Kaithal. The highest mean value of $\mathrm{Ca}^{2+}\left(4.84 \mathrm{mgL}^{-1}\right)$ was observed in the sewage water of Charkhi Dadri while $\mathrm{Mg}^{2+}\left(7.41 \mathrm{mg} \mathrm{L}^{-1}\right)$ and $\mathrm{Na}^{+}\left(10.50 \mathrm{mg} \mathrm{L}^{-1}\right)$ were recorded highest in the sewage water of Narwana. The mean value of $\mathrm{K}^{+}$content was highest $\left(2.07 \mathrm{mg} \mathrm{L}^{-1}\right)$ in the sewage water of Jind district. The mean values of anions like carbonates $\left(\mathrm{CO}_{3}{ }^{2-} 0.90 \mathrm{mg} \mathrm{L}^{-1}\right)$ and bicarbonates $\left(\mathrm{HCO}_{3}^{-} 4.52 \mathrm{mg} \mathrm{L}^{-1}\right)$ were highest in district Jind, sulphate $\left(\mathrm{SO}_{4}{ }^{2-} 0.74 \mathrm{mg} \mathrm{L}^{-1}\right)$ in district Kaithal and $\mathrm{Cl}^{-}\left(12.06 \mathrm{mg} \mathrm{L}^{-1}\right)$ in the sewage water of Narwana. Highest mean value of zinc $(0.19 \mathrm{mg}$ $\left.\mathrm{L}^{-1}\right)$ content was observed in the sewage water of Kaithal. The highest mean value of copper $(0.20$ $\mathrm{mg} \mathrm{L}^{-1}$ ) was observed in sewage water of Kurukshetra and Kaithal district. The highest mean value of Fe $\left(6.45 \mathrm{mg} \mathrm{L}^{-1}\right)$ was observed in the sewage water of Kurukshetra district. The highest mean value of $\mathrm{Mn}\left(0.48 \mathrm{mg} \mathrm{L}^{-1}\right)$ was observed in the sewage water of Kaithal district. The mean value of cadmium $(\mathrm{Cd})$ was highest in the sewage water of Jind $\left(0.31 \mathrm{mg} \mathrm{L}^{-1}\right)$. Chromium $(\mathrm{Cr})$ content was absent in the sewage and non-sewage water collected from all the sites in Haryana. The mean value of lead $(\mathrm{Pb})\left(0.13 \mathrm{mg} \mathrm{L}^{-1}\right)$ was highest in the sewage water of Kaithal. The mean value of cobalt $(\mathrm{Co})$ $\left(0.06 \mathrm{mg} \mathrm{L}^{-1}\right)$ was highest in the sewage water of Kurukshetra district.

\section{Introduction}

Population growth, especially in the developing countries, has increased the demand for a huge quantity of water for domestic, municipal, and industrial sectors. With the increasing scarcity of fresh water resources that are available to agriculture, the use of urban waste water for irrigation is increasing. The growth of towns, cities, and development of industries by $19^{\text {th }}$ century leads to problem of disposal of sewage, which encouraged the use of sewage wastewater in irrigation. Waste water is composed of 99.9 per cent water and 0.1 per cent of other materials (suspended colloidal and dissolved solids). The practice of use of domestic sewage in farming is becoming prevalent as the demand of water is increasing. Due to fast industrial development and the growth of population, the availability of water decreases day-to- day. This increase in the population has led to increased demand of water and the increased generation of waste water. The high quality water is preserved and the lower quality is used for agricultural purposes. 
Irrigation with sewage became a prevalent practice in arid and semiarid regions, where it was readily available and economic to freshwater. The final aim of sewage management is the protection of the environment which the ultimate goal of wastewater management in a manner corresponding with public health and socioeconomic concerns. The increase in world population has not only put pressure on limited water resources but also increased the volume of waste generation (Darvishi et al., 2010). The growing competition for scarce water resources, coupled with law of limiting ground water pumping, has led to utilization of low quality water in irrigated agriculture.

An estimated 38,354 million litres per day of sewage water is generated in major cities of India. The sewage water is a potential water resource with stability of water quantity and reliable supply. Nutrients and water being the most critical inputs in agriculture, harvesting the nutrients and irrigation potential of sewage water are of prime importance for maximizing the food, fodder and fuel production. Sewage water is a rich source of both beneficial and harmful elements. Many small to medium scale industries operating in peri-urban residential areas of cities dispose their contaminated effluents directly in sewage system.

The composition of sewer waters is dependent on the composition and quantity of the industrial effluents discharged into the sewer systems (Kirkham, 1974; Larsen et al., 1975; Arora et al., 1985) thus, the resultant sewer water contains variable amounts of plant nutrients, toxic metals, oils, grease, fat and soluble salts. The raw sewer water gets entry into the agricultural fields and may affect the soil, plants, human and animal health, depending upon its composition (Anderson and Nilsson, '1973; Gupta et al., 1986, 1994; Narwal et al., 1990).
Opportunities exist as sewage effluents from municipal origin are rich in organic matter and also contain appreciable amounts of major and micronutrients (Feign et al., 1991; Pescod, 1992; Gupta et al., 1998; Brar et al., 2000). Accordingly nutrient levels of soils are expected to improve considerably with continuous irrigation with sewage (Baddesha et al., 1986; Narwal et al., 1993; Brar et al., 2000). The increased competition for freshwater among urban and semi-urban centres, industries and agriculture, particularly irrigated agriculture under severe pressure as irrigation has been the largest user of water (Van der Hoek et al., 2002). Therefore, the use of treated, partially-treated or untreated wastewater has received more attention (Yao et al., 2013). Bouwer (1994) stressed about the need of water management on local, regional, national and international level. Keeping the above facts in view, the study was undertaken to evaluate the chemical composition of sewage and non-sewage water of peri-urban area of Haryana state so as to use this water for agricultural purposes.

\section{Materials and Methods}

\section{Study area}

The present study has been conducted in Haryana state which is one the northern state of India. The geographical location of the state is between $27^{\circ} 39^{\prime}$ to $30^{\circ} 35^{\prime} \mathrm{N}$ latitude and $74^{\circ} 28^{\prime}$ and $77^{\circ} 36^{\prime} \mathrm{E}$ longitude. In present study, five districts were selected for the present study namely (i) Kurukshetra, (ii) Kaithal, (iii) Narwana, (iv) Jind and (v) Charkhi Dadri. In each district, four sites were selected for the sampling of sewage and nonsewage sources of water. From each site two sample of sewage and two sample of nonsewage water were collected from discharge out-lets. The sewage water sample were collected in duplicate, i.e. one already treated with a mixture of $1: 1 \mathrm{HNO}_{3}$ and distilled 
water to avoid adsorption of heavy metals on the walls of bottle and in another un-acidified bottle rinsed with only distilled water. Unacidified sewage water samples were used for the determination of $\mathrm{pH}, \mathrm{EC}, \mathrm{COD}, \mathrm{BOD}$, soluble cations and anions, micro-nutrients and heavy metals.

\section{Sample analysis}

The $\mathrm{pH}$ was determined by systronic digital pH meter (Jackson, 1973). Electrical conductivity was estimated in the filtered sample with the help of Elico conductivity meter bridge (Jackson, 1973). Biological oxygen demand was calculated by multiplying organic matter content of sewage water by 0.711 (Schulz, 1938). The chemical oxygen demand (COD) of sewage water was determined by open reflux method (Tandon, 1998). $\mathrm{Ca}^{2+}$ was estimated by compleximeteric titration with standard $0.01 \mathrm{~N}$ EDTA and $\mathrm{pH}-$ 12 obtained with the help of $\mathrm{NaOH}$ by using ammonium purpurate as indicator, when pink colour of the solution changed to purple (Jackson, 1973). $\mathrm{Mg}^{2+}$ was estimated by titrating with $0.01 \mathrm{~N}$ EDTA by buffering the solution to $\mathrm{pH} 10$ with $\mathrm{NH}_{4} \mathrm{Cl}-\mathrm{NH}_{4} \mathrm{OH}$ buffer by using Erichrome black $\mathrm{T}$ indicator (Jackson, 1973). $\mathrm{Na}^{+}$was determined by flame photometer with the help of a standard curve outlined by (Jackson, 1973). $\mathrm{K}^{+}$was determined by flame photometer with the help of a standard curve outlined by (Jackson, 1967). $\mathrm{CO}_{3}{ }^{2-}$ and $\mathrm{HCO}_{3}{ }^{2-}$ was estimated by titrating a known volume of the sewage water with standard $\mathrm{H}_{2} \mathrm{SO}_{4}$ first in the presence of phenolphthalein and then with methyl red indicator (Richards, 1954). $\mathrm{Cl}^{-}$was determined by titrating with standard $(0.02 \mathrm{~N}) \mathrm{AgNO}_{3}$ solution using potassium chromate as indicator. The end point was obtained when white precipitate of $\mathrm{AgCl}$ change to brick red colour suggesting complete precipitation of chloride with $\mathrm{Ag}$ (Richards, 1954). $\mathrm{SO}_{4}{ }^{2-}$ was determined by EDTA-titration method as described by (Chesnin and Yien, 1951). Total $\mathrm{Zn}, \mathrm{Cu}, \mathrm{Mn}, \mathrm{Fe}, \mathrm{Cd}, \mathrm{Pb}, \mathrm{Co}$, and $\mathrm{Cr}$ were estimated in acidified digested samples using atomic absorption spectrophotometer (AAS). The statistical analysis was accomplished by Statistical Software Package for Agricultural Research Workers (Sheoran et al., 1998).

\section{Results and Discussion}

Chemical and biological composition of sewage and non-sewage water in some cities of Haryana is presented in table 1 . The $\mathrm{pH}$ value of sewage water was found higher (8.49 to 8.58) in the sewage water of Kaithal followed by Kurukshetra (8.31 to 8.36), Narwana (8.10 to 8.40 ), Jind (8.00 to 8.42 ) and Charkhi Dadri (8.00 to 8.12). The mean $\mathrm{pH}$ value of the sewage water collected from all the sites was higher (8.54) as compared to the $\mathrm{pH}$ of non-sewage water (8.22). The $\mathrm{pH}$ of sewage water ranged from 8.00 to 8.58 whereas it was ranged from 7.80-8.28 in nonsewage water. The EC value of sewage water was found higher (1.63 to $2.18 \mathrm{dSm}^{-1}$ ) in the sewage water of Kaithal followed by Kurukshetra (1.51 to $1.27 \mathrm{dSm}^{-1}$ ), Narwana (1.08 to $\left.1.57 \mathrm{dSm}^{-1}\right)$, Jind (1.05 to $1.63 \mathrm{dSm}^{-1}$ ) and Charkhi Dadri (1.04 to $1.13 \mathrm{dSm}^{-1}$ ). The mean EC value of the sewage water collected from all the sites was higher $\left(1.91 \mathrm{dSm}^{-1}\right)$ as compared to the EC of non-sewage water $\left(0.34 \mathrm{dSm}^{-1}\right)$. Electrical conductivity of sewage water ranged from 1.04 to $2.18 \mathrm{dSm}^{-1}$ where as it was ranged from 0.19 to $0.35 \mathrm{dSm}^{-}$

${ }^{1}$ in non-sewage water. Similar results were reported by Singh et al., (2017) during their survey of five sites in Haryana and revealed that $\mathrm{pH}$ and electrical conductivity of sewage and industrial effluents irrigated soils was much higher than tube well water irrigated soils. Also in the present study the sewage water had the $\mathrm{pH}$ in the range from 8.00 to 8.58 and when it was applied in the soils, it resulted into slight decrease in the $\mathrm{pH}$ (7.70 to $8.40)$ at $0-15 \mathrm{~cm}$ depth while at higher depth 
$15-30 \mathrm{~cm}$ it was ranged from 7.75 to 8.70 . The decrease in the soil $\mathrm{pH}$ due to sewage water might be ascribed to the reason that sewage water is slightly alkaline in nature. The EC of sewage water ranged from 1.1 to $3.8 \mathrm{dSm}^{-1}$ which may cause salinity in soil and ultimately restricting the plant growth (Antil, 2012). Similar results were corroborated by Yadav et al., (2003), Abril (2005), Hussain (2005) and Sial et al., (2006).

The COD value of sewage water was found higher $\left(652.00\right.$ to $\left.872.00 \mathrm{mg} \mathrm{L}^{-1}\right)$ in the sewage water of Kaithal followed by Kurukshetra (470.00 to $510.00 \mathrm{mg} \mathrm{L}^{-1}$ ), Narwana $\left(470.00\right.$ to $\left.628.00 \mathrm{mg} \mathrm{L}^{-1}\right)$, Jind (460.00 to $485.00 \mathrm{mg} \mathrm{L}^{-1}$ ) and Charkhi Dadri (450.00 to $467.50 \mathrm{mg} \mathrm{L}^{-1}$ ). The mean COD value of the sewage water collected from all the sites was higher $\left(762.00 \mathrm{dSm}^{-1}\right)$ as compared to the COD of non-sewage water $\left(172.50 \mathrm{dSm}^{-1}\right)$. The COD of sewage water ranged from $450-872 \mathrm{mg} \mathrm{L}^{-1}$ whereas it was ranged from $92-180 \mathrm{mg} \mathrm{L}^{-1}$ in non-sewage water.

The BOD value of sewage water was found higher (190.00 to $250.00 \mathrm{mg} \mathrm{L}^{-1}$ ) in the sewage water of Kaithal followed by Kurukshetra (220.00 to $\left.235.00 \mathrm{mg} \mathrm{L}^{-1}\right)$, Narwana (150.00 to $\left.160.00 \mathrm{mg} \mathrm{L}^{-1}\right)$, Jind (120.00 to $180.00 \mathrm{mg} \mathrm{L}^{-1}$ ) and Charkhi Dadri (120.00 to $140.00 \mathrm{mg} \mathrm{L}^{-1}$ ). The mean value of BOD in sewage water was found higher (227.5 $\mathrm{mg} \mathrm{L} \mathrm{L}^{-1}$ ) in Kaithal followed by Kurukshetra (220.0 mg L $\left.{ }^{-1}\right)$, Narwana (155.0 $\mathrm{mgL}^{-1}$ ), Jind (150.0 $\mathrm{mg} \mathrm{L}^{-1}$ ) and Charkhi Dadri $\left(130.0 \mathrm{mg} \mathrm{L}^{-1}\right.$ ). The mean BOD of the sewage water collected from all the sites was higher (227.50 $\mathrm{mg} \mathrm{L}^{-1}$ ) as compared to the BOD (77.50 $\mathrm{mg} \mathrm{L}^{-1}$ ) of non-sewage water. The BOD of sewage water ranged from 120-250 $\mathrm{mg} \mathrm{L}^{-1}$ whereas it was ranged from 40 to 80 $\mathrm{mg} \mathrm{L}^{-1}$ in non-sewage water. The BOD of sewage water ranged from $120-250 \mathrm{mg} \mathrm{L}^{-1}$ and it was found higher as compared to the permission limit $\left(100 \mathrm{mg} \mathrm{L}^{-1}\right)$ prescribed for the effluent to be discharged on land for irrigation (100 $\mathrm{mg} \mathrm{L}^{-1}$, ISI Standard, 1982). These results corroborated with the findings of Arora et al., (1985) for municipal waste water of Ludhiana and according to Yadav et al., (2003) and Karthikeyan and Singh (2004) for sewage waters from different districts of Haryana State. Similar results were also reported by Dubey et al., (2007).

Water soluble cations and anions in sewage and non-sewage water

Sewage water contains all the cations and anions in higher amounts as compared to nonsewage water. The cations like $\mathrm{Ca}^{2+}, \mathrm{Mg}^{2+}$, $\mathrm{Na}^{+}$and $\mathrm{K}^{+}$in sewage water ranged from 2.16 to $5.12,5.12$ to $7.84,5.69$ to 11.43 and 0.64 to $2.29 \mathrm{mg} \mathrm{L}^{-1}$, respectively, while these were ranged from 1.15 to $2.10,2.55$ to $4.65,2.63$ to 5.60 and 0.25 to $0.52 \mathrm{mg} \mathrm{L}^{-1}$ in non-sewage water, respectively. Similar results were reported by Yadav et al., (2003), Azevedo et al., (2005), Nayan et al., (2012), Blum et al., (2013).

The highest mean value of $\mathrm{Ca}^{2+}\left(4.84 \mathrm{mgL}^{-1}\right)$ was observed in the sewage water of Charkhi Dadri while $\mathrm{Mg}^{2+}\left(7.41 \mathrm{mg} \mathrm{L}^{-1}\right)$ and $\mathrm{Na}^{+}$ $\left(10.50 \mathrm{mg} \mathrm{L}^{-1}\right)$ were recorded highest in the sewage water of Narwana. The mean value of $\mathrm{K}^{+}$content was higher $\left(2.07 \mathrm{mg} \mathrm{L}^{-1}\right)$ in the sewage water of Jind district. Sodium content were found highest $\left(10.50 \mathrm{mg} \mathrm{kg}^{-1}\right)$ in the soils irrigated with sewage water in Narwana and lowest $\left(6.56 \mathrm{mg} \mathrm{kg}^{-1}\right)$ in Kurukshetra.

The mean values of anions like $\left(\mathrm{CO}_{3}{ }^{2-} 0.90 \mathrm{mg}\right.$ $\left.\mathrm{L}^{-1}\right)$ and $\left(\mathrm{HCO}_{3}^{-} 4.52 \mathrm{mg} \mathrm{L}^{-1}\right)$ were highest in district Jind, sulphate $\left(\mathrm{SO}_{4}{ }^{2-} 0.74 \mathrm{mg} \mathrm{L}^{-1}\right)$ in district Kaithal and $\mathrm{Cl}^{-}\left(12.06 \mathrm{mg} \mathrm{L}^{-1}\right)$ in the sewage water of Narwana. All the anions like $\mathrm{CO}_{3}{ }^{2-}, \mathrm{HCO}_{3}{ }^{-}, \mathrm{Cl}^{-}, \mathrm{SO}_{4}{ }^{2-}$ in sewage water ranged from 0.20 to $0.98,2.45$ to $4.56,5.64$ to 12.47 and 1.68 to $3.46 \mathrm{mg} \mathrm{L}^{-1}$ respectively, 
while the non-sewage water contains 0.11 to $0.33,0.42$ to $2.85,1.54$ to 5.87 and 0.21 to $0.97 \mathrm{mg} \mathrm{L}^{-1}$ respectively. Both the ions i.e. sodium and chloride are meant for specific ion toxicity. These ions from soil or water can be accumulated in the root zone of the sensitive plants and can cause enough toxicity which ultimately reduces the yield (Ayers and
Wescott, 1985). However, in present study the sodium (2.63 to $5.60 \mathrm{mg} \mathrm{L}^{-1}$ ) and chloride ions (5.64 to $12.47 \mathrm{mg} \mathrm{L}^{-1}$ ) were found safe as per the permissible limit given by Azul (2002) (Table 1). The sulphates ranged from 1.68 to $3.46 \mathrm{mg} \mathrm{L}^{-1}$ in the sewage water of different cities in Haryana but within the permissible limit (Table 5).

Table.1 Chemical and biological composition of sewage and non-sewage water in some cities of Haryana

\begin{tabular}{|l|c|c|c|c|c|c|c|c|}
\hline \multirow{2}{*}{ Location } & \multicolumn{2}{|c|}{ Ph } & \multicolumn{2}{c|}{ EC $\left(\mathbf{d S m}^{-\mathbf{1}}\right)$} & \multicolumn{2}{c|}{ COD $\left(\mathbf{m g ~ L}^{-1}\right)$} & \multicolumn{2}{c|}{ BOD $\left(\mathbf{m g ~ L}^{-1}\right)$} \\
\cline { 2 - 9 } & Sewage & $\begin{array}{c}\text { Non- } \\
\text { Sewage }\end{array}$ & Sewage & $\begin{array}{c}\text { Non- } \\
\text { sewage }\end{array}$ & Sewage & $\begin{array}{c}\text { Non- } \\
\text { sewage }\end{array}$ & Sewage & $\begin{array}{c}\text { Non- } \\
\text { sewage }\end{array}$ \\
\hline $\begin{array}{l}\text { Kurukshetra- } \\
\text { 1 }\end{array}$ & 8.36 & 8.28 & 1.51 & 0.32 & 510.00 & 180.00 & 250.00 & 70.00 \\
\hline $\begin{array}{l}\text { Kurukshetra- } \\
\text { Mean }\end{array}$ & 8.31 & 8.10 & 1.27 & 0.30 & 470.00 & 165.00 & 190.00 & 50.00 \\
\hline Kaithal-1 & $\mathbf{8 . 3 4}$ & $\mathbf{8 . 1 9}$ & $\mathbf{1 . 3 9}$ & $\mathbf{0 . 3 1}$ & $\mathbf{4 9 0 . 0 0}$ & $\mathbf{1 7 2 . 5 0}$ & $\mathbf{2 2 0 . 0 0}$ & $\mathbf{6 0 . 0 0}$ \\
\hline Kaithal-2 & 8.49 & 8.00 & 1.63 & 0.29 & 652.00 & 110.00 & 220.00 & 75.00 \\
\hline Mean & $\mathbf{8 . 5 4}$ & $\mathbf{8 . 1 2}$ & $\mathbf{1 . 9 1}$ & $\mathbf{0 . 3 1}$ & $\mathbf{7 6 2 . 0 0}$ & $\mathbf{1 2 0 . 0 0}$ & $\mathbf{2 2 7 . 5 0}$ & $\mathbf{7 7 . 5 0}$ \\
\hline Narwana-1 & 8.40 & 8.19 & 1.57 & 0.32 & 628.00 & 128.00 & 160.00 & 80.00 \\
\hline Narwana-2 & 8.10 & 8.24 & 1.08 & 0.35 & 470.00 & 145.00 & 150.00 & 40.00 \\
\hline Mean & $\mathbf{8 . 2 5}$ & $\mathbf{8 . 2 2}$ & $\mathbf{1 . 3 3}$ & $\mathbf{0 . 3 4}$ & $\mathbf{5 4 9 . 0 0}$ & $\mathbf{1 3 6 . 5 0}$ & $\mathbf{1 5 5 . 0 0}$ & $\mathbf{6 0 . 0 0}$ \\
\hline Jind-1 & 8.00 & 7.96 & 1.05 & 0.27 & 510.00 & 108.00 & 120.00 & 60.00 \\
\hline Jind-2 & 8.42 & 7.81 & 1.63 & 0.23 & 460.00 & 92.00 & 180.00 & 80.00 \\
\hline Mean & $\mathbf{8 . 2 1}$ & $\mathbf{7 . 8 9}$ & $\mathbf{1 . 3 4}$ & $\mathbf{0 . 2 5}$ & $\mathbf{4 8 5 . 0 0}$ & $\mathbf{1 0 0 . 0 0}$ & $\mathbf{1 5 0 . 0 0}$ & $\mathbf{7 0 . 0 0}$ \\
\hline $\begin{array}{l}\text { Charkhi } \\
\text { Dadri-1 }\end{array}$ & 8.12 & 7.80 & 1.21 & 0.19 & 485.00 & 150.00 & 120.00 & 40.00 \\
\hline $\begin{array}{l}\text { Charkhi } \\
\text { Dadri-2 }\end{array}$ & 8.00 & 7.93 & 1.04 & 0.24 & 450.00 & 160.00 & 140.00 & 60.00 \\
\hline Mean & $\mathbf{8 . 0 6}$ & $\mathbf{7 . 8 7}$ & $\mathbf{1 . 1 3}$ & $\mathbf{0 . 2 2}$ & $\mathbf{4 6 7 . 5 0}$ & $\mathbf{1 5 5 . 0 0}$ & $\mathbf{1 3 0 . 0 0}$ & $\mathbf{5 0 . 0 0}$ \\
\hline Range & $8.00-$ & $7.80-$ & $1.04-$ & $0.19-$ & $450-$ & $92-180$ & $120-$ & $40-80$ \\
\hline
\end{tabular}


Table.2 Cation and anion composition of sewage and non-sewage water in different cities of Haryana

\begin{tabular}{|c|c|c|c|c|c|c|c|c|c|c|c|c|c|c|c|c|}
\hline \multirow[t]{3}{*}{ Location } & \multicolumn{8}{|c|}{ Cations $\left(\mathrm{mg} \mathrm{L}^{-1}\right)$} & \multicolumn{8}{|c|}{ Anions $\left(\mathrm{mg} \mathrm{L}^{-1}\right)$} \\
\hline & \multicolumn{2}{|c|}{$\mathrm{Ca}^{2+}$} & \multicolumn{2}{|c|}{$\mathrm{Mg}^{2+}$} & \multicolumn{2}{|c|}{$\mathrm{Na}^{+}$} & \multicolumn{2}{|c|}{$\mathbf{K}^{+}$} & \multicolumn{2}{|c|}{$\mathrm{CO}_{3}{ }^{2-}$} & \multicolumn{2}{|c|}{$\mathrm{HCO}_{3}{ }^{-}$} & \multicolumn{2}{|c|}{$\mathrm{Cl}^{-}$} & \multicolumn{2}{|c|}{$\mathrm{SO}_{4}{ }^{2-}$} \\
\hline & SW & NSW & SW & NSW & SW & NSW & SW & NSW & SW & NSW & SW & NSW & SW & NSW & SW & NSW \\
\hline Kurukshetra-1 & 4.72 & 1.54 & 7.68 & 3.24 & 7.42 & 2.70 & 2.15 & 0.25 & 0.34 & 0.15 & 3.10 & 0.52 & 7.35 & 1.57 & 3.45 & 0.84 \\
\hline Kurukshetra-2 & 4.24 & 1.23 & 5.12 & 3.58 & 5.69 & 3.10 & 1.96 & 0.52 & 0.21 & 0.11 & 2.45 & 0.42 & 5.64 & 1.72 & 2.83 & 0.64 \\
\hline Mean & 4.48 & 1.39 & 6.40 & 3.41 & 6.56 & 2.90 & 2.06 & 0.39 & 0.28 & 0.13 & 2.78 & 0.47 & 6.50 & 1.65 & 3.14 & 0.74 \\
\hline Kaithal-1 & 2.38 & 1.50 & 6.56 & 3.05 & 9.36 & 2.63 & 1.56 & 0.50 & 0.61 & 0.33 & 4.21 & 2.85 & 8.24 & 2.05 & 3.46 & 0.97 \\
\hline Kaithal-2 & 2.16 & 1.21 & 6.25 & 2.98 & 5.97 & 2.87 & 1.31 & 0.35 & 0.42 & 0.28 & 3.35 & 1.22 & 6.68 & 1.54 & 3.12 & 0.84 \\
\hline Mean & 2.27 & 1.36 & 6.41 & 3.02 & 7.67 & 2.75 & 1.44 & 0.43 & 0.52 & 0.31 & 3.78 & 2.04 & 7.46 & 1.80 & 3.29 & 0.91 \\
\hline Narwana-1 & 3.55 & 1.32 & 7.84 & 3.98 & 11.43 & 5.60 & 0.85 & 0.40 & 0.84 & 0.12 & 4.12 & 2.65 & 12.47 & 5.87 & 2.61 & 0.25 \\
\hline Narwana-2 & 2.64 & 1.15 & 6.97 & 3.69 & 9.57 & 4.87 & 0.64 & 0.35 & 0.55 & 0.21 & 3.85 & 2.55 & 11.64 & 4.13 & 2.39 & 0.36 \\
\hline Mean & 3.10 & 1.24 & 7.41 & 3.84 & 10.50 & 5.24 & 0.75 & 0.38 & 0.70 & 0.17 & 3.99 & 2.60 & 12.06 & 5.00 & 2.50 & 0.31 \\
\hline Jind-1 & 4.27 & 1.95 & 6.54 & 3.20 & 10.12 & 3.10 & 1.84 & 0.34 & 0.81 & 0.21 & 4.56 & 2.45 & 9.74 & 3.95 & 2.71 & 0.52 \\
\hline Jind-2 & 3.86 & 2.10 & 5.18 & 4.65 & 8.64 & 2.68 & 2.29 & 0.41 & 0.98 & 0.19 & 4.48 & 2.34 & 7.46 & 3.67 & 3.01 & 0.33 \\
\hline Mean & 4.07 & 2.03 & 5.86 & 3.93 & 9.38 & 2.89 & 2.07 & 0.38 & 0.90 & 0.20 & 4.52 & 2.40 & 8.60 & 3.81 & 2.86 & 0.43 \\
\hline $\begin{array}{l}\text { Charkhi } \\
\text { Dadri-1 }\end{array}$ & 5.12 & 1.22 & 7.45 & 2.55 & 8.91 & 4.20 & 1.34 & 0.25 & 0.34 & 0.11 & 4.51 & 1.68 & 6.95 & 2.74 & 1.68 & 0.27 \\
\hline $\begin{array}{l}\text { Charkhi } \\
\text { Dadri-2 }\end{array}$ & 4.56 & 1.65 & 6.78 & 3.41 & 8.72 & 3.54 & 1.12 & 0.52 & 0.20 & 0.17 & 3.20 & 1.53 & 5.81 & 1.56 & 2.05 & 0.21 \\
\hline Mean & 4.84 & 1.44 & 7.12 & 2.98 & 8.82 & 3.87 & 1.23 & 0.39 & 0.27 & 0.14 & 3.86 & 1.61 & 6.38 & 2.15 & 1.87 & 0.24 \\
\hline Range & $\begin{array}{c}2.16- \\
5.12\end{array}$ & $\begin{array}{l}1.15- \\
2.10\end{array}$ & $\begin{array}{l}5.12- \\
7.84\end{array}$ & $\begin{array}{c}2.55- \\
4.65\end{array}$ & $\begin{array}{l}5.69- \\
11.43\end{array}$ & $\begin{array}{c}2.63- \\
5.60\end{array}$ & $\begin{array}{c}0.64- \\
2.29\end{array}$ & $\begin{array}{c}0.25- \\
0.52\end{array}$ & $\begin{array}{c}0.20- \\
0.98\end{array}$ & $\begin{array}{c}0.11- \\
0.33\end{array}$ & $\begin{array}{l}2.45- \\
4.56\end{array}$ & $\begin{array}{c}0.42- \\
2.85\end{array}$ & $\begin{array}{l}5.64- \\
12.47\end{array}$ & $\begin{array}{l}1.54- \\
5.87\end{array}$ & $\begin{array}{l}1.68- \\
3.46\end{array}$ & $\begin{array}{c}0.21- \\
0.97\end{array}$ \\
\hline
\end{tabular}


Table.8 Micro-nutrients and heavy metals in sewage and non-sewage water of different cities in Haryana

\begin{tabular}{|c|c|c|c|c|c|c|c|c|c|c|c|c|c|c|c|c|}
\hline \multirow[t]{3}{*}{ Location } & \multicolumn{8}{|c|}{ Micro-nutrients $\left(\mathrm{mg} \mathrm{L}^{-1}\right)$} & \multicolumn{8}{|c|}{ Heavy metals $\left(\mathrm{mg} \mathrm{L}^{-1}\right)$} \\
\hline & \multicolumn{2}{|c|}{ Zn } & \multicolumn{2}{|c|}{$\mathbf{C u}$} & \multicolumn{2}{|c|}{$\mathrm{Fe}$} & \multicolumn{2}{|c|}{ Mn } & \multicolumn{2}{|c|}{ Cd } & \multicolumn{2}{|c|}{$\mathrm{Cr}$} & \multicolumn{2}{|c|}{$\mathbf{P b}$} & \multicolumn{2}{|c|}{ Co } \\
\hline & $\mathbf{S}$ & NS & $\mathbf{S}$ & NS & $\mathbf{S}$ & NS & $\mathbf{S}$ & NS & $\mathbf{S}$ & NS & $\mathbf{S}$ & NS & $\mathbf{S}$ & NS & $\mathbf{S}$ & NS \\
\hline Kurukshetra-1 & 0.13 & 0.03 & 0.20 & 0.03 & 6.17 & 0.02 & 0.14 & 0.00 & 0.31 & 0.00 & 0.00 & 0.00 & 0.13 & 0.01 & 0.05 & 0.00 \\
\hline Kurukshetra-2 & 0.10 & 0.02 & 0.20 & 0.01 & 6.73 & 0.01 & 0.23 & 0.00 & 0.29 & 0.00 & 0.00 & 0.00 & 0.11 & 0.01 & 0.06 & 0.00 \\
\hline Mean & 0.12 & 0.03 & 0.20 & 0.02 & 6.45 & 0.02 & 0.19 & 0.00 & 0.30 & 0.00 & 0.00 & 0.00 & 0.12 & 0.01 & 0.06 & 0.00 \\
\hline Kaithal-1 & 0.20 & 0.01 & 0.19 & 0.01 & 4.28 & 0.01 & 0.43 & 0.01 & 0.25 & 0.00 & 0.00 & 0.00 & 0.13 & 0.01 & 0.03 & 0.00 \\
\hline Kaithal-2 & 0.18 & 0.01 & 0.20 & 0.01 & 3.12 & 0.00 & 0.52 & 0.01 & 0.28 & 0.00 & 0.00 & 0.00 & 0.12 & 0.01 & 0.03 & 0.00 \\
\hline Mean & 0.19 & 0.01 & 0.20 & 0.01 & 3.70 & 0.01 & 0.48 & 0.01 & 0.27 & 0.00 & 0.00 & 0.00 & 0.13 & 0.01 & 0.03 & 0.00 \\
\hline Narwana-1 & 0.08 & 0.01 & 0.23 & 0.03 & 4.30 & 0.01 & 0.13 & 0.00 & 0.22 & 0.00 & 0.00 & 0.00 & 0.09 & 0.00 & 0.01 & 0.00 \\
\hline Narwana-2 & 0.10 & 0.01 & 0.14 & 0.01 & 5.12 & 0.00 & 0.22 & 0.00 & 0.19 & 0.00 & 0.00 & 0.00 & 0.10 & 0.00 & 0.01 & 0.00 \\
\hline Mean & 0.09 & 0.01 & 0.19 & 0.02 & 4.71 & 0.01 & 0.18 & 0.00 & 0.21 & 0.00 & 0.00 & 0.00 & 0.10 & 0.00 & 0.01 & 0.00 \\
\hline Jind-1 & 0.11 & 0.02 & 0.12 & 0.01 & 3.56 & 0.01 & 0.16 & 0.00 & 0.30 & 0.00 & 0.00 & 0.00 & 0.14 & 0.02 & 0.01 & 0.00 \\
\hline Jind-2 & 0.12 & 0.02 & 0.14 & 0.02 & 2.11 & 0.02 & 0.22 & 0.00 & 0.31 & 0.00 & 0.00 & 0.00 & 0.11 & 0.00 & 0.02 & 0.00 \\
\hline Mean & 0.12 & 0.02 & 0.13 & 0.02 & 2.84 & 0.02 & 0.19 & 0.00 & 0.31 & 0.00 & 0.00 & 0.00 & 0.12 & 0.01 & 0.02 & 0.00 \\
\hline $\begin{array}{l}\text { Charkhi Dadri- } \\
1\end{array}$ & 0.14 & 0.02 & 0.11 & 0.01 & 3.18 & 0.01 & 0.31 & 0.00 & 0.18 & 0.05 & 0.00 & 0.00 & 0.08 & 0.01 & 0.04 & 0.00 \\
\hline $\begin{array}{l}\text { Charkhi Dadri- } \\
2\end{array}$ & 0.13 & 0.01 & 0.13 & 0.01 & 4.08 & 0.01 & 0.28 & 0.00 & 0.20 & 0.00 & 0.00 & 0.00 & 0.07 & 0.03 & 0.03 & 0.00 \\
\hline Mean & 0.14 & 0.02 & 0.12 & 0.01 & 3.63 & 0.01 & 0.30 & 0.00 & 0.19 & 0.03 & 0.00 & 0.00 & 0.08 & 0.02 & 0.04 & 0.00 \\
\hline Range & $\begin{array}{c}0.08- \\
0.20\end{array}$ & $\begin{array}{l}0.01- \\
0.03\end{array}$ & $\begin{array}{l}0.11- \\
0.23\end{array}$ & $\begin{array}{l}0.01- \\
0.03\end{array}$ & $\begin{array}{l}2.11- \\
6.73\end{array}$ & $\begin{array}{l}0.00- \\
0.02\end{array}$ & $\begin{array}{l}0.13- \\
0.52\end{array}$ & $\begin{array}{c}0.00- \\
0.01\end{array}$ & $\begin{array}{l}0.18- \\
0.31\end{array}$ & $\begin{array}{l}0.00- \\
0.05\end{array}$ & $\begin{array}{c}0.00- \\
0.00\end{array}$ & $\begin{array}{l}0.00- \\
0.00\end{array}$ & $\begin{array}{l}0.07- \\
0.14\end{array}$ & $\begin{array}{l}0.00- \\
0.03\end{array}$ & $\begin{array}{c}0.01- \\
0.06\end{array}$ & $\begin{array}{c}0.00- \\
0.00\end{array}$ \\
\hline
\end{tabular}


Table.3 Correlation of EC with $\mathrm{pH}, \mathrm{Cl}^{-}, \mathrm{SO}_{4}{ }^{2-}, \mathrm{Ca}^{2+}, \mathrm{Mg}^{2+}, \mathrm{Na}^{+}, \mathrm{K}^{+}, \mathrm{CO}_{3}{ }^{2-}$ and $\mathrm{HCO}_{3}{ }^{2}$

\begin{tabular}{|c|c|c|}
\hline Variables & $\begin{array}{c}\text { Pearson Correlation } \\
\text { Coefficient }\end{array}$ & P value \\
\hline $\mathbf{p H}$ & $0.739^{*}$ & 0.0002 \\
\hline $\mathbf{C l}$ & $0.942^{* *}$ & $<.0001$ \\
\hline $\mathbf{S O}_{4}{ }^{2-}$ & $0.976^{* *}$ & $<.0001$ \\
\hline $\mathbf{C a}^{2+}$ & $0.964^{* *}$ & $<.0001$ \\
\hline $\mathbf{M g}^{2+}$ & $0.966^{* *}$ & $<.0001$ \\
\hline $\mathbf{N a}^{+}$ & $0.965^{* *}$ & $<.0001$ \\
\hline $\mathbf{K}^{+}$ & $0.966^{* *}$ & $<.0001$ \\
\hline $\mathbf{C O}_{3}{ }^{2-}$ & $0.890^{* *}$ & $<.0001$ \\
\hline $\mathbf{H C O}_{3}{ }^{2-}$ & $0.881^{* *}$ & $<.0001$ \\
\hline
\end{tabular}

*Significant at $\mathrm{P}=0.05$ level; ** Significant at $\mathrm{P}=0.0001$ level

Table.4 Correlation of $\mathrm{pH}$ with $\mathrm{EC}, \mathrm{Cl}^{-}, \mathrm{SO}_{4}{ }^{2-}, \mathrm{Ca}^{2+}, \mathrm{Mg}^{2+}, \mathrm{Na}^{+}, \mathrm{K}^{+}, \mathrm{CO}_{3}{ }^{2-}$, and $\mathrm{HCO}_{3}{ }^{2}$

\begin{tabular}{|c|c|c|}
\hline $\mathbf{E C}$ & $\mathbf{0 . 7 3 9}$ & $\mathbf{0 . 0 0 0 2}$ \\
\hline $\mathbf{C l}$ & $0.860^{* *}$ & $<.0001$ \\
\hline $\mathbf{S O}^{2-}$ & $0.768^{* *}$ & $<.0001$ \\
\hline $\mathbf{C a}^{2+}$ & $0.842^{* *}$ & $<.0001$ \\
\hline $\mathbf{M g}^{2+}$ & $0.796^{* *}$ & $<.0001$ \\
\hline $\mathbf{N a}^{+}$ & $0.823^{* *}$ & $<.0001$ \\
\hline $\mathbf{K}^{+}$ & $0.827^{* *}$ & $<.0001$ \\
\hline $\mathbf{C O}^{2-}$ & $0.888^{* *}$ & $<.0001$ \\
\hline $\mathbf{H C O}_{3}{ }^{2-}$ & $0.912^{* *}$ & $<.0001$ \\
\hline
\end{tabular}

*Significant at $\mathrm{P}=0.05$ level; ** Significant at $\mathrm{P}=0.0001$ level

Table.5 Tolerance limits for inland surface water, Class - E (irrigation, industrial cooling or controlled waste disposal)

\begin{tabular}{|c|l|c|c|c|}
\hline $\begin{array}{c}\text { S } \\
\text { No. }\end{array}$ & Characteristic & $\begin{array}{c}\text { Values in present } \\
\text { study }\left(\mathbf{m g ~ L}^{-\mathbf{1}}\right)\end{array}$ & $\begin{array}{c}\text { Tolerance } \\
\text { limit }\end{array}$ & Inference \\
\hline 1. & Sulphates $\left(\mathrm{SO}_{4}{ }^{2-}\right)(\max )$. & $1.68-3.46$ & 1000 & In limit \\
\hline 2. & Chlorides $\left(\mathrm{Cl}^{-}\right)($max.) & $5.67-12.47$ & 600 & In limit \\
\hline
\end{tabular}

Source: Indian Standards (1982)

Table.6 Micronutrient status of sewage water in Kaithal district

\begin{tabular}{|c|c|c|c|}
\hline Micro-nutrient & $\begin{array}{c}\text { Sewage water } \mathbf{( m g ~ \mathbf { L } ^ { - }} \\
\mathbf{1})\end{array}$ & Permissible limit $\left.\mathbf{( m g ~ L}^{\mathbf{- 1}}\right)$ & Inference \\
\hline Zinc & 0.19 & $<2.0$ & In limit \\
\hline Copper & 0.20 & 0.20 & In limit \\
\hline Manganese & 0.43 & 0.20 & Higher \\
\hline
\end{tabular}


Table.7 Correlation among organic matter at $0-15 \mathrm{~cm}$ of soil with the heavy metals present in sewage water

\begin{tabular}{|l|c|c|c|c|c|}
\hline Variables & $\begin{array}{c}\text { CEC } \\
{\left[\mathbf{c m o l}(+) \mathbf{~ k g}^{-\mathbf{1}}\right]}\end{array}$ & $\begin{array}{c}\text { Organic } \\
\text { carbon }(\boldsymbol{\%})\end{array}$ & \multicolumn{2}{|c|}{$\begin{array}{c}\text { Pd } \\
\left(\mathbf{m g ~ L}^{-1}\right)\end{array}$} & $\mathbf{C o}$ \\
\hline CEC [cmol (+) $\left.\mathbf{~ k g}^{-\mathbf{1}}\right]$ & 1 & & & & \\
\hline Organic carbon $(\boldsymbol{\%})$ & $0.832^{\mathrm{NS}}$ & 1 & & & \\
\hline Cd & $0.569^{\mathrm{NS}}$ & $0.879^{*}$ & 1 & & \\
\hline Pb & $0.405^{\mathrm{NS}}$ & $0.831^{\mathrm{NS}}$ & $0.862^{\mathrm{NS}}$ & 1 & \\
\hline Co & $0.814^{\mathrm{NS}}$ & $0.571^{\mathrm{NS}}$ & $0.252^{\mathrm{NS}}$ & $0.065^{\mathrm{NS}}$ & 1 \\
\hline
\end{tabular}

*Significant at $\mathrm{P}=0.05$ level

Correlation of $\mathrm{EC}$ with $\mathrm{pH}, \mathrm{Cl}^{-}, \mathrm{SO}_{4}{ }^{2-}, \mathrm{Ca}^{2+}$, $\mathrm{Mg}^{2+}, \mathrm{Na}^{+}, \mathrm{K}^{+}, \mathrm{CO}_{3}{ }^{2-}$ and $\mathrm{HCO}_{3}{ }^{2-}$

The EC values of sewage water collected from all the sites under study have strongly positive correlation with $\mathrm{pH}, \mathrm{Cl}^{-}, \mathrm{SO}_{4}{ }^{2-}, \mathrm{Ca}^{2+}$, $\mathrm{Mg}^{2+}, \mathrm{Na}^{+}, \mathrm{K}^{+}, \mathrm{CO}_{3}{ }^{2-}$, and $\mathrm{HCO}_{3}{ }^{2-}$.

The $\mathrm{pH}$ of sewage water is significantly and positively correlated with EC $(\mathrm{P} \leq 0.05)$ while EC was positively correlated with all the cations and anions $(\mathrm{P} \leq 0.0001)$ level depicting that an increase in the soluble anions and cations resulted an increase in the $\mathrm{EC}$ of the sewage water while the EC of the non-sewage water was quite low as compared to EC of the sewage water from all the sites under study (Table 3 ).

Correlation of pH with $\mathrm{EC}, \mathrm{Cl}^{-}, \mathrm{SO}_{4}{ }^{2-}, \mathrm{Ca}^{2+}$, $\mathrm{Mg}^{2+}, \mathrm{Na}^{+}, \mathrm{K}^{+}, \mathrm{CO}_{3}{ }^{2-}$, and $\mathrm{HCO}_{3}{ }^{2-}$

The $\mathrm{pH}$ values of sewage water collected from all the sites under study have strongly positive correlation with $\mathrm{EC}, \mathrm{Cl}^{-}, \mathrm{SO}_{4}^{2-}, \mathrm{Ca}^{2+}$, $\mathrm{Mg}^{2+}, \mathrm{Na}^{+}, \mathrm{K}^{+}, \mathrm{CO}_{3}{ }^{2-}$, and $\mathrm{HCO}_{3}{ }^{2-}$. $\mathrm{EC}$ of the sewage water is significantly and positively correlated with $\mathrm{pH}$ at $(\mathrm{P} \leq 0.05)$ level while $\mathrm{pH}$ have highly and positive correlation with all the cations and anions at $(\mathrm{P} \leq 0.0001)$ level indicated that increase in the soluble anions and cations resulted into increase in the $\mathrm{pH}$ of the sewage water while the $\mathrm{pH}$ of non-sewage water was quite low as compared to $\mathrm{pH}$ value of the sewage water collected from all the sites under study (Table 4).

\section{Micronutrients and heavy metals in sewage} and non-sewage water

Zinc ( $\mathrm{Zn}), \mathrm{Cu}, \mathrm{Fe}$ and $\mathrm{Mn}$ were higher in sewage water as compared to non-sewage water of all the cities under study. The zinc content in the sewage water varied from 0.08 to $0.20 \mathrm{mg} \mathrm{L}^{-1}$ while it was 0.01 to $0.03 \mathrm{mg} \mathrm{L}^{-}$ 1 in non-sewage water. The highest mean value of zinc content was observed in the sewage water collected from Kaithal $(0.19 \mathrm{mg}$ $\left.\mathrm{L}^{-1}\right)$. The $\mathrm{Cu}$ content in sewage water ranged from 0.11 to $0.23 \mathrm{mg} \mathrm{L}^{-1}$ while it ranged from 0.01 to $0.03 \mathrm{mg} \mathrm{L}^{-1}$ in non-sewage water. The highest mean value of copper was observed $\left(0.20 \mathrm{mg} \mathrm{L}^{-1}\right)$ in sewage water of Kurukshetra and Kaithal district. The Fe content in sewage water ranged from 2.11 to $6.73 \mathrm{mg} \mathrm{L}^{-1}$ while it ranged from 0.00 to $0.02 \mathrm{mg} \mathrm{L}^{-1}$ in nonsewage water. The highest mean value of $\mathrm{Fe}$ content in sewage water $\left(6.45 \mathrm{mg} \mathrm{L}^{-1}\right)$ was observed in Kurukshetra district while it was only $0.02 \mathrm{mg} \mathrm{L}^{-1}$ in non-sewage water of Jind and Kurukshetra. Manganese content in the sewage water ranged from 0.13 to $0.52 \mathrm{mg} \mathrm{L}^{-}$ ${ }^{1}$ while it was ranged from 0.00 to $0.01 \mathrm{mg} \mathrm{L}^{-1}$ in non-sewage water. The highest mean value of Mn content $\left(0.48 \mathrm{mg} \mathrm{L}^{-1}\right)$ in sewage water was observed in Kaithal district while it was only $0.01 \mathrm{mg} \mathrm{L}^{-1}$ in non-sewage water of Kaithal. 
Micronutrients like $\mathrm{Zn}, \mathrm{Cu}, \mathrm{Fe}, \mathrm{Mn}$ are essential for plant growth (Wintz et al., 2002). Zinc $\left(0.19 \mathrm{mg} \mathrm{L}^{-1}\right)$, copper $\left(0.2 \mathrm{mg} \mathrm{L}^{-1}\right)$ and Manganese $\left(0.43 \mathrm{mg} \mathrm{L}^{-1}\right)$ were found higher in sewage water of Kaithal as compared to other districts. The permissible limit of zinc, copper and manganese in sewage water is $<2.0,0.2$ and 0.20 , respectively (Table 7 ) while iron was higher in the sewage water of Kurukshetra (Table 52 \& Fig 6). Heavy metals like cadmium (Cd) was found highest in the sewage water of Jind $\left(0.31 \mathrm{mg} \mathrm{L}^{-1}\right)$ followed by Kurukshetra $\left(0.30 \mathrm{mg} \mathrm{L}^{-1}\right)$ while $\mathrm{Pb}$ was found highest in sewage water of Kaithal district (Table 7). Antil (2012) reported $\mathrm{Cd}$ range in Haryana soils under the influence of sewage water was 0.15 to 5.80 $\mathrm{mg} \mathrm{L}^{-1}$. In present study, the concentration of $\mathrm{Fe}, \mathrm{Mn}, \mathrm{Zn}$, and $\mathrm{Cu}$ was higher in sewage water as compared to non-sewage water and indicates that sewage water is a good source of micronutrient and help to correct their deficiency and reduces the application of costly chemical fertilizers (Kharache et al., 2011).

Sewage contains higher amounts of heavy metals like the $\mathrm{Cd}$ ranged from 0.18 to 0.31 , $\mathrm{Pb} 0.07$ to 0.14 , Co 0.01 to $0.06 \mathrm{mg} \mathrm{L}^{-1}$. The mean value of Cadmium was higher in the sewage water of Jind $\left(0.31 \mathrm{mg} \mathrm{L}^{-1}\right)$ and Kurukshetra district $\left(0.30 \mathrm{mg} \mathrm{L}^{-1}\right)$. Chromium content was absent in the sewage and nonsewage water collected from all the sites in Haryana. The mean value of $\mathrm{Pb}\left(0.13 \mathrm{mg} \mathrm{L}^{-1}\right)$ was found higher in the sewage water of Kaithal. The mean value of Co $\left(0.06 \mathrm{mg} \mathrm{L}^{-1}\right)$ was found higher in the sewage water of Kurukshetra district.

From the above study it can be concluded that in the sewage water, the $\mathrm{pH}$, electrical conductivity, calcium carbonate, chemical oxygen demand, biological oxygen demand, water soluble anions and cations, micronutrients and heavy metals were found higher amount as compared to non-sewage water. These chemical properties of the sewage water make it safe to use it for irrigating the fields at the time of water scarcity, drought spells or under limited supply and waste water management conditions. This can be strengthened in the peri-urban areas to reduce the cost of cultivation by providing micro nutrients from waste water.

\section{References}

Anderson, A. \& Nilsson, K. 0. (1973). Enrichment of trace elements from sewage sludge fertilizers in soils and plants Ambio., 1, 176-179.

Antil, R.S. (2012). Impact of sewage and industrial effluents on soil-plant health. In Industrial Waste. InTech.

Arora, B. R., Azad, A. S., Bijay, Singh \&Sekhon, G. S. (1985). Pollution potential of municipal waste waters of Ludhiana, Punjab. Indian J. Ecol., 12, 1-7.

Baddesha HS, Rao DLN, Abrol IP, Chhabra $R$. Irrigation and nutrient potential of raw sewage waters of Haryana. Indian $\mathbf{J}$ Agric Sci 1986; 56(8): 584- 91.

Bajwa, H. (2008). Water contamination causing DNA mutation. The Indian Express, pp. 5, Feb. 16, 2008, Chandigarh edition, India.

Bouwer, H. 1994. Irrigation and global water outlook. Agricultural Water Management. 25: 221-231.

Brar MS, Mahli SS, Singh AP, Arora CL, Gill KS. Sewer water irrigation effects on some potentially toxic trace elements in soil and potato plants in northwestern India. Can J Soil Sci 2000; 80: 465-71.

Darvishi, H.H., Manshouri, M., Farahani, H.A., 2010.The effect of irrigation by domestic wastewater on soil properties. J. Soil Sci. Environ. Manag. 1 (2), 030033. 
Dheri, G.S., Brar, M.S. and Malhi, S.S. (2007). Heavy- metal concentration of sewage- contaminated water and its impact on underground water, soil, and crop plants in alluvial soils of northwestern India. Communications in soil science and plant analysis, 38(910): $1353-1370$.

Feign A, Ravina I, Shalhevet J. Irrigation with treated sewage effluent: management for environmental protection. Berlin: Springer; 1991.

Gruenhage, L. andJager I.I.J. (1985). Effect of heavy metals on growth and heavy metals content of Allium Porrum and Pisumsativum.Angewandte Botnik, 59: $11-28$.

Gupta AP, Narwal RP, Antil RS. Sewer water composition and its effect on soil properties. Bioresour Technol 1998; 65: $171-3$.

Gupta, A. P., Antil, R. S. \&Anoop Singh. (1986). Composition of some sewer water and their effect on soil properties. pp. 419-425. In Proc. Natl. Seminar on Monitoring and Control of Environmental Pollution, held at CSIRO, Chandigarh, Oct. 22-24.

Huang, C.V., Bazzaz, F.A. and Venderhoef, L.N. (1974). The inhibition of soybean metabolism by cadmium and lead. Plant Physiology, 34: 122-124.

Juwarkar, A.S. and Shende, G.B. (1986) Interaction of $\mathrm{Cd}-\mathrm{Pb}$ effect on growth yield and content of $\mathrm{Cd}, \mathrm{Pb}$ in barley. Indian Journal of Environmental Health, 28: 235-24.

Khan, Z.I., Zahara, B., Ahmed, K. and Asraf, M. (2014). Appraisal of heavy metal concentrations in edible vegetable Abelmoschus esculentus (Lady Finger) grown in soil irrigated with domestic sewage water in Sargodha, Pakistan. Arab Gulf Journal of Scientific Research. 32(2/3): 169-177.

Kharche, V.K., Desai, V.N. and Pharande,
A.L. (2011). Effect of sewage irrigation on soil properties, essential nutrients and pollutant element status of soils and plants in a vegetable growing area around Ahmednagar city in Maharashtra. Journal of Indian Society of Soil Science, 59:177-184.

Kirkham, B. M. (1974). Disposal of sludge on land - effects on soils, plants and ground water Compost Sci., 15, 6-10.

Larsen, W. E., Gilley, J. R. \& Linden, D. R. (1975).Consequences of waste disposal on land. Soil Water Cons., 2, 68-71.

Morzck, E Jr. and Funicclli, N.A. (1982). Effect of lead and on germination of Spartinaalterniflora Losiel seeds at various salinities. Environmental and Experimental Botany, 22: 23-32.

Mukherjiz, S. and Maitra, P. (1976). Toxic effects of lead growth and metabolism of germinating rice (Oryza sativa L.) seeds mitosis of onion (Allium cepa) root tip cells. Indian Journal of Experimental Biology, 14:519-521.

Narwal RP, Gupta AP, Anoop-Singh, Karwasra SS. Composition of some city waste waters and their effect on soil characteristics. Ann Biol 1993; 9: 23945.

Narwal, R. P., Gupta, A. P., Anoop Singh \& Karwasra, S. P. S. (1990). Pollution potential of some sewer waters of Haryana. pp. 121-126. In Recent Advances in Environmental Pollution and Management. Haryana Pollution Control Board \& Haryana Agricultural University Hisar.

Pescod MB. Wastewater treatment and use in agriculture. Bull FAO 1992; 47:125 [Rome].

Sheoran, O.P; Tonk, D.S; Kaushik, L.S; Hasija, R.C \& Pannu, R.S (1998). Statistical Software Package for Agricultural Research Workers. Recent Advances in Information Theory, Statistics \& Computer Applications by 
D.S. Hooda \& R.C. Hasija, Department of Mathematics Statistics, CCS HAU, Hisar (139-143).

Sudhakar, C., Symalabai, L. and Veeranjaveyuler, K. (1992). Lead tolerance of certain legume species grown on lead or tailing. Agricultural Ecological and Environment, 41: 253261.

Van der Hoek, W., Ul-Hassan, M., Ensink,
J.H.J., Feenstra, S., Raschid-Sally, L., Munir, S., Aslam, R., Ali, N., Hussain, R., Matsuno, Y., 2002. Urban wastewater in Pakistan: a valuable resource for agriculture. Research Report 63.IWMI, Colombo, Sri Lanka.

Wintz, H., Fox, T. and Vulpe, C. (2002). Responses of plants to iron, zinc and copper deficiencies Biochemical Society Transactions, 30: 766-768.

\section{How to cite this article:}

Sushil, R. S. Garhwal and Dinesh. 2019. Composition of Sewage and Non-Sewage Water of Different District of Haryana, India. Int.J.Curr.Microbiol.App.Sci. 8(09): 2771-2782. doi: https://doi.org/10.20546/ijcmas.2019.809.319 